\title{
COMPARATIVE STUDY OF THE NORMAL VISBREAKING PROCESS AND THE THERMAL FIXED-BED PROCESS APPLIED ON COLOMBIAN HEAVY OILS
}

\author{
ESTUDIO COMPARATIVO DEL PROCESO DE VISCORREDUCCIÓN NORMAL \\ Y EL PROCESO TÉRMICO CON LECHO FIJO APLICADO \\ A CRUDOS PESADOS COLOMBIANOS
}

Judith-Rocío Santa-Jaimes*1 and Jairo-Javier López-Gómez²

\author{
'Ecopetrol S.A. - Instituto Colombiano del Petróleo (ICP), A.A. 4185 Piedecuesta, Santander, Colombia \\ ${ }^{2}$ TIP Ltda., Piedecuesta, Santander, Colombia \\ e-mail: judith.santa@ecopetrol.com.co
}

(Received: Sep. 24, 2013; Accepted: Oct. 28, 2014)

\section{ABSTRACT}

T

he rise in heavy oil reserves, the scarceness of light oils, the demand for clean products and the increase in residual material or bottoms make it necessary to implement or adapt technologies to process heavy oils efficiently. To this end, the modification of the current visbreaking system has been proposed, consisting of adapting a fixed bed inside the reactor in order to study possible modifications in the different thermal processes to increment and improve performance with the purpose of obtaining more valuable products from heavy oils.

This research was conducted through testing at the pilot plant level in the visbreaking unit of Ecopetrol S.A. Instituto Colombiano del Petróleo (ICP), which provides the possibility of comparing the normal visbreaking process to the fixed-bed visbreaking process as a thermal process. Both processes are carried out in comparison to the increase in the performance of middle distillates and the quality properties of the products obtained. The comparison was completed under the same conditions of flow, flow direction (ascending), pressure, temperature and oil type.

The results revealed that the fixed-bed visbreaking process managed to convert more heavy fractions into distillates (4 to $7 \%$ ) compared to the normal visbreaking process.

Keywords: Thermal cracking, Visbreaking, Delayed coking, Heavy oils, Reactors, Fixed-bed, Distillates.

How to cite: Santa-Jaimes, J. R. \& López-Gómez, J. J. (2014). Comparative study of the normal visbreaking process and the thermal fixed-bed process applied on Colombian heavy oils. CT\&F - Ciencia, Tecnología y Futuro, 5(5), 75-96.

${ }^{*}$ To whom correspondence should be addressed 
$\mathrm{E}$ I aumento en las reservas de crudos pesados, la escasez de crudos livianos, la demanda de productos limpios y el incremento de material residual o fondos, hacen necesaria la implementación o adaptación de tecnologías que procesen crudos pesados de forma eficiente. En este sentido se plantea la modificación del esquema actual de viscorreducción adaptándole un lecho fijo dentro del reactor para estudiar posibles modificaciones en los diferentes procesos térmicos, a fin de incrementar y mejorar sus rendimientos con miras a la obtención de productos más valiosos a partir de crudos pesados.

La presente investigación se realizó mediante pruebas a nivel de planta piloło en la unidad de viscorreducción de Ecopetrol S.A. - Instituto Colombiano del Petróleo (ICP), la cual brinda la posibilidad de comparar el proceso de viscorreducción normal frente al proceso de viscorreducción con lecho fijo como proceso térmico. Ambos procesos se compararon en cuanto al incremento del rendimiento de destilados medios y propiedades de calidad de los productos obtenidos. La comparación se hizo bajo las mismas condiciones de flujo, dirección de flujo (ascendente), presión, temperatura y tipo de crudo.

Los resultados revelaron que el proceso de viscorreducción con lecho fijo logró convertir más fracciones pesadas en destilados (4 a 7\%), comparado con el proceso de viscorreducción normal.

Palabras clave: Craqueo térmico, Viscorreducción, Coquización retardada, Crudos pesados, Reactores, Lecho fijo, Destilados.

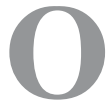

aumento nas reservas de crus pesados, a escassez de crus leves, a demanda de produtos limpos e o aumento de material residual ou fundos, fazem necessária a implantação ou adaptação de tecnologias que processem crus pesados de forma eficiente. Neste sentido é proposta a modificação do esquema atual de viscorredução adaptando-Ihe um leito fixo dentro do reator para estudar possíveis modificações nos diferentes processos térmicos, com a finalidade de aumentar e melhorar seus rendimentos com vista à obtenção de produtos mais valiosos a partir de crus pesados.

A presente pesquisa foi realizada mediante provas a nível de centro piloto na unidade de viscorredução de Ecopetrol S.A. - Instituto Colombiano del Petróleo (ICP), a qual oferece a possibilidade de comparar o processo de viscorredução normal diante do processo de viscorredução com leito fixo como processo térmico. Ambos os processos são comparados em quanto ao aumento do rendimento de destilados médios e propriedades de qualidade dos produtos obtidos. A comparação foi feita sob as mesmas condições de fluxo, direção de fluxo (ascendente), pressão, temperatura e tipo de cru.

Os resultados revelaram que o processo de viscorredução com leito fixo conseguiu converter mais frações pesadas em destilados (4 a 7\%), comparado com o processo de viscorredução normal.

Palavras chave: Craqueamento térmico, Viscorredução, Coqueamento retardado, Crus pesados, Reatores, Leito fixo, Destilados. 


\section{INTRODUCTION}

The visbreaking process substantially reduces the viscosity of reduced oils and vacuum bottoms through thermal conversion, compared to other important thermal processes (Gary \& Handwerk, 2001; CorredorRojas \& Valero-Alvarado, 2004). Future developments or variations of this visbreaking process will depend on the trends in product specifications, and mainly on the types of oils available in the world, such as extra heavy oils (Pantoja, 2005). Therefore, this research analyzes a modification of the thermal visbreaking process in order to generate higher yields and more valuable products. The modification proposed herein suggests a thermal technology using heavy and extra heavy oils as raw material, which will be the only source of oil available in the future.

In doing so, this paper analyzes the effect of the presence of inert solids in the fixed bed reactor of the thermal process, in order to observe its impact and the improvement of the products in the presence thereof. In addition, it analyzes the advantages and disadvantages of this variation in the process.

The basic principle that supports the introduction of a fixed bed with inert solids in the visbreaking reactor is based on the fact that when the oil comes into contact with fixed solids in a thermal process, it leads to a more efficient, homogeneous heat transfer, thus inducing an extra thermal cracking process on the surface thereof (Bartholic \& Watchung, 1979). This makes it possible for the thermal process with the fixed bed to convert more heavy fractions into light ones, thus generating much more valuable products than those generated in the normal visbreaking process.

Ivanhoe Energy (2013) has conducted previous research related to this topic, which has also studied the introduction of inert solids in the thermal cracking process. This technology is known as Heavy to Light (HTL). The HTL technological variant cracks the heavy oil thermally and converts it into a lighter fluid without the use of solvents, which facilitates the transport and use thereof by refineries (Colyar, 2010). This technology decreases the carbon from the oil through processes at high temperatures with circulating inert solids, creating a Synthetic Crude Oil (SCO) (Ivanhoe Energy, 2013). The thermal fixed-bed process is different from the HTL process in the dynamics of the solids in the reactor and other operating conditions. Despite the difference of the two processes, their yields are comparable.

This paper compares both thermal processes under the same conditions of flow, flow direction (ascending), pressure, temperature and bottom or oil type, in order to isolate the effect caused only by inert solids on the qualities of final thermally cracked products. The operational parameters that were evaluated in the bottom products generated by both thermal processes at the same conditions were: fractions and naphtha yields, residence times and quality of products. This last aspect covers: sulfur, Conradson carbon, insolubles in n-heptane, total metals, viscosity, API gravity and stability.

\section{METHODOLOGY}

In order to analyze the effect of the presence of inert solids in the thermal process, 15 runs were carried out with reduced Colombian oil and 5 runs with vacuum bottoms at the visbreaking pilot plant with a capacity of $15 \mathrm{~mL} / \mathrm{min}$ located at Ecopetrol S.A. - Instituto Colombiano del Petróleo (ICP).

Both the materials and the methodology used in this research are discussed in the following sections.

\section{Materials}

\section{Reduced Oil and Vacuum Bottoms}

The reduced oil and vacuum bottoms used in this research were provided by Ecopetrol S.A. All the fluids used in the experiments were generated during normal refinery operations in the first half of 2012.

The reduced oil and vacuum bottoms evaluated in this research arrived at the facilities of Ecopetrol S.A. - Instituto Colombiano del Petróleo (ICP) completely sealed. They were preserved according to the standards for storage. Table 1 illustrates the characteristics of the oils and bottoms evaluated in both processes. 
Table 1. Characteristics of the oils and bottoms evaluated.

\begin{tabular}{|c|c|c|c|c|c|c|c|c|}
\hline Analysis & Units & Standard & $\begin{array}{l}\text { Reduced } \\
\text { Oil A }\end{array}$ & $\begin{array}{l}\text { Reduced } \\
\text { Oil B }\end{array}$ & $\begin{array}{l}\text { Reduced } \\
\text { Oil C }\end{array}$ & $\begin{array}{l}\text { Reduced } \\
\text { Oil D }\end{array}$ & $\begin{array}{l}\text { Vacuum } \\
\text { Bottom } 1\end{array}$ & $\begin{array}{l}\text { Vacuum } \\
\text { Bottom } 2\end{array}$ \\
\hline Leco sulfur & weight \% & ASTM D4294-10 & 3.13 & 1.64 & 1.52 & 3 & 3.3 & 2.04 \\
\hline $\begin{array}{l}\text { Micro carbon } \\
\text { residue }\end{array}$ & weight \% & ASTM D4530- 11 & 23.2 & 17.4 & 14.9 & 33.3 & 32.8 & 28.7 \\
\hline P-value & - & $\begin{array}{c}\text { SMS } 1600 \\
\text { (ASTM D7060-12) }\end{array}$ & 1 & 1.15 & 1.45 & 2.95 & 1.9 & 2.35 \\
\hline Merit test & - & Rodríguez, 2014 & NA & NA & NA & NA & 3 & NA \\
\hline Stability criteria & - & - & Unstable & Unstable & Stable & Stable & Stable & Stable \\
\hline Insolubles in n-C7 & weight $\%$ & ASTM D3279-12 & 20.4 & 16.2 & 9.25 & 20.4 & 31.7 & 22.7 \\
\hline Viscosity at $80^{\circ} \mathrm{C}$ & $\mathrm{cP}$ & ASTM D445-14e2 & 51400 & 2488 & NA & 49900 & NA & ND \\
\hline Viscosity at $100^{\circ} \mathrm{C}$ & cP & ASTM D445-14e2 & 7176 & 570 & NA & 6777 & NA & 169100 \\
\hline Viscosity at $120^{\circ} \mathrm{C}$ & $\mathrm{CP}$ & ASTM D445-14e2 & 1648 & 190 & NA & 1503 & NA & 17110 \\
\hline Calcium & $\mathrm{mg} / \mathrm{kg}$ & UOP 389-14 & 2.11 & 1.38 & 100 & 2.58 & 2.35 & 3.88 \\
\hline Chromium & $\mathrm{mg} / \mathrm{kg}$ & UOP 389-14 & 0.03 & 0.03 & 4.67 & 0.03 & 0.03 & 0.05 \\
\hline Iron & $\mathrm{mg} / \mathrm{kg}$ & UOP 389-14 & 9.08 & 3.06 & 5.29 & 7.94 & 12.2 & 7.6 \\
\hline Sodium & $\mathrm{mg} / \mathrm{kg}$ & UOP 389-14 & 4.42 & 3.53 & 10.8 & 1.5 & 2.51 & 7.72 \\
\hline Nickel & $\mathrm{mg} / \mathrm{kg}$ & UOP 389-14 & 136 & 49.4 & 56.7 & 134 & 195 & 110 \\
\hline Vanadium & $\mathrm{mg} / \mathrm{kg}$ & UOP 389-14 & 584 & 192 & 207 & 581 & 774 & 404 \\
\hline Aluminum & $\mathrm{mg} / \mathrm{kg}$ & ASTM D5184-12 & 0.91 & 2.04 & 2.28 & 0.71 & 1.45 & N/A \\
\hline Silicon & $\mathrm{mg} / \mathrm{kg}$ & ASTM D5184-12 & 2.47 & 2.4 & 3.35 & 0.63 & 5.65 & N/A \\
\hline Total metals & $\mathrm{mg} / \mathrm{kg}$ & UOP 389-14 & 739 & 253 & 390 & 728 & 993 & 533 \\
\hline API Gravity & ${ }^{\circ} \mathrm{API}$ & $\begin{array}{l}\text { ASTM D1250-08(2013) } \\
\text { /ASTM D5002-13 }\end{array}$ & 4.8 & 8.8 & 10.6 & 4.2 & 0.3 & 5 \\
\hline $\begin{array}{l}\text { Simulated } \\
\text { distillation by } \\
\text { fractions }\end{array}$ & \multicolumn{8}{|c|}{ Simulated distillation high temperature oils $36-740+C$} \\
\hline
\end{tabular}

\section{Inert Filler Material for the Fixed Bed}

For quality control purposes, quartz sand was chosen as the inert filler material for the fixed bed. This material was used to ensure that the solids introduced in the visbreaking reactor were inert.

To do so, $99 \%$ purity quartz sand was acquired, whose grain surface was free from clay, with no common minerals such as ilmenite, magnitite, and with traces
$(<1 \%)$ of zircon and rutile, which met the ASTM E11 13 quality specifications listed in Table 2 .

\section{Visbreaking Reactor}

The reactor has a volume of $294.5 \mathrm{~mL}$ in 316 stainless steel, a diameter of $2.54 \mathrm{~cm}$ and a length of $60 \mathrm{~cm}$. It is part of the visbreaking pilot unit of Ecopetrol S.A. Instituto Colombiano del Petróleo (ICP) (see Figure 1).

Table 2. Characteristics of the quartz sand used in the research.

\begin{tabular}{|c|c|c|c|c|c|c|c|c|c|c|}
\hline $\begin{array}{c}\text { Sample of } \\
\text { quartz sand } \\
\text { mesh }\end{array}$ & $\begin{array}{c}\text { Thermal } \\
\text { conductivity } \\
\left(\mathrm{W} / \mathrm{m}^{2}\right)\end{array}$ & $\begin{array}{c}\text { Specific } \\
\text { heat } \\
(\mathrm{kcal} / \mathrm{kg})\end{array}$ & $\begin{array}{c}\text { Particle } \\
\text { diameter } \\
(\mu \mathrm{m})\end{array}$ & $\begin{array}{c}\text { Dry } \\
\text { weight } \\
\text { (g) }\end{array}$ & $\begin{array}{l}\text { Grain } \\
\text { vol. } \\
\left(\mathrm{cm}^{3}\right)\end{array}$ & $\begin{array}{c}\text { Bulk } \\
\text { density } \\
\left(\mathrm{g} / \mathrm{cm}^{3}\right)\end{array}$ & $\begin{array}{l}\text { Grain } \\
\text { density } \\
\left(\mathrm{g} / \mathrm{cm}^{3}\right)\end{array}$ & $\begin{array}{c}\text { Pore vol. } \\
\left(\mathrm{cm}^{3}\right)\end{array}$ & $\begin{array}{c}\text { Porosity } \\
\text { (\%) }\end{array}$ & $\begin{array}{l}\text { Bulk } \\
\text { vol. } \\
\left(\mathrm{cm}^{3}\right)\end{array}$ \\
\hline $60-70$ & 45.2 & 0.27 & $212-250$ & 73.93 & 28.07 & 1.571 & 2.634 & 19 & 0.4036 & 47.06 \\
\hline
\end{tabular}


In the case of the fixed-bed runs, a small stainless steel basket was pressure inserted to keep the inert material still during the operation. The basket was made with the same length as the isothermal zone of the reactor and then placed in the same area.
The isothermal zone had a length of $16 \mathrm{~cm}$ and a volume of $78.54 \mathrm{~mL}$ as illustrated in Figure 1. Table 3 shows the configurations of the reactor volumes for normal visbreaking and fixed-bed visbreaking.
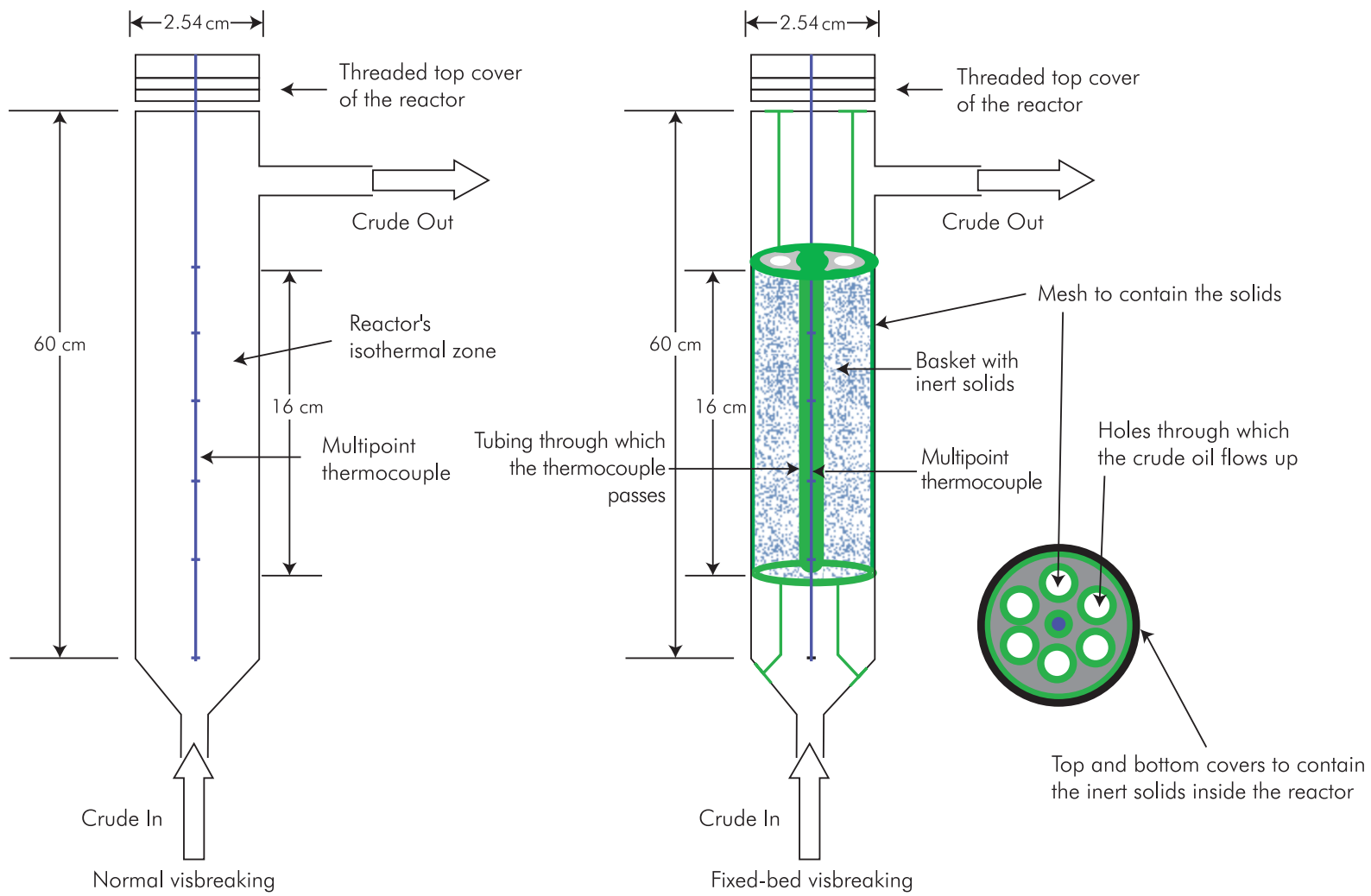

Figure 1. Normal and fixed-bed visbreaking reactor.

Table 3. Run conditions.

\begin{tabular}{|cccc|}
\hline Operating conditions & Units & $\begin{array}{c}\text { Visbreaking } \\
\text { (without fixed-bed) }\end{array}$ & $\begin{array}{c}\text { Visbreaking } \\
\text { (with fixed-bed) }\end{array}$ \\
\hline Void volume of the reactor & $\mathrm{mL}$ & 294.52 & 245.52 \\
\hline Void volume of the isothermal zone & $\mathrm{mL}$ & 78.54 & 29.54 \\
\hline Volume of sand added & $\mathrm{mL}$ & $\mathrm{NA}$ & 1.407 \\
\hline Sand density & $\mathrm{g} / \mathrm{mL}$ & $\mathrm{NA}$ & 69 \\
\hline Sand mass added & $\mathrm{g}$ & $\mathrm{min}$ & $2.23-2.41$ \\
\hline Space velocity & $\mathrm{min}^{-1}$ & $0.44-0.41$ & $0.84-0.88$ \\
\hline${ }^{\circ} \mathrm{C}$ & $450-530$ & $1.19-1.13$ \\
\hline
\end{tabular}


In each run, the basket was loaded with clean inert solids, then closed and the pressure inserted in the isothermal zone of the reactor.

All the experiments were conducted with ascending flow to mitigate liquid distribution problems that arise in fixed-bed reactors with descending flow, such as channeling (Fogler, 1979; Smith, 1991; Froment \& Bischoff, 1979; Iborra, Tejero \& Cunill, 2013; Levenspiel, 1999).

In addition, the reactor is installed in the furnace and programmed at different operating conditions for each run.

\section{Flowchart of the Visbreaking Pilot Unit}

The unit included a feed section, with preheating and a feed pump; a reaction section, which includes the reactor and furnace; a separation section, which includes a separator and condenser, and finally, the gas collection and measurement system (see Figure 2).

\section{Methodology}

The following section describes the methodology used in the evaluation of normal and fixed-bed visbreaking processes.

\section{Evaluation Runs in Pilot Plants}

For both processes, the mass and pressure flow parameters were kept constant at $35 \mathrm{~g} / \mathrm{min}$ and 14.7 psia respectively. All other conditions of the runs are listed in Table 3.

\section{Technical Procedure at the Pilot unit}

The procedure followed was established for the visbreaking pilot unit. The variation in the process was the installation of the fixed-bed system.

The steps below were followed:

- Runs with fixed bed: Introduction of inert solids in the basket installed inside the visbreaking reactor.

- Stabilization of reactor temperature.

- Temperature ramp scheduled to increase furnace temperature gradually up to the specific reaction temperature.

- Stabilization of reaction temperature in the reactor.

- Start of the actual run at programmed conditions.

- End of the actual run.

- Collection of products of the actual run and quantification thereof.

- Mass balances of the run.

The runs were carried out in duplicate to ensure repeatability in the data.

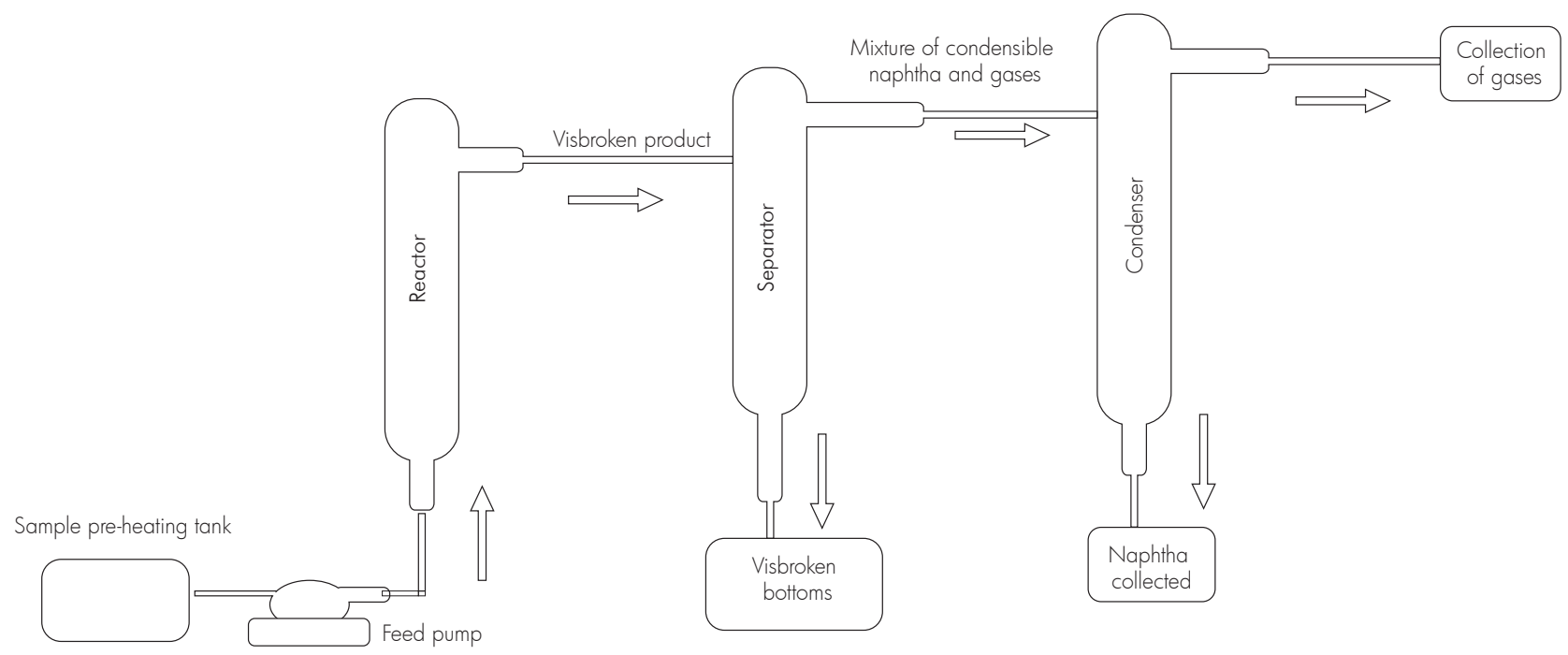

Figure 2. Flowchart of the visbreaking pilot unit. 


\section{RESULTS}

The different results are shown by type of feed and each type of process evaluated.

\section{Reduced Oil A}

Table 4 shows the operating conditions with the results of the mass balances and physical chemical properties in the normal visbreaking processes and the thermal fixed-bed process for Reduced Oil A. Replicas were carried out for most of them with good reproducibility results; however, due to their physical chemical properties, some oils could not be evaluated using the same characteristics of the product.

\section{Yield by Distilled Fractions}

Figure 3 shows the different fractions obtained in the normal visbreaking and thermal fixed-bed processes using Reduced Oil A.

\section{Percentage Recovered at $460^{\circ} \mathrm{C}$ and Naphtha Yields}

Figure 4 shows the results of the percentages recovered at $460^{\circ} \mathrm{C}$ and the naphtha yields of the normal visbreaking process and the thermal fixed-bed process using Reduced Oil A.

Table 4. Overall results for Reduced Oil A.

\begin{tabular}{|c|c|c|c|c|}
\hline \multirow{2}{*}{\multicolumn{2}{|c|}{ Data analyzed }} & \multicolumn{3}{|c|}{ Type of process } \\
\hline & & Visbreaking & Fixed-bed & Fixed-bed \\
\hline \multicolumn{2}{|c|}{ Residence time in isothermal zone (min) } & 2.3 & 0.9 & 0.9 \\
\hline \multicolumn{2}{|c|}{ Reaction temperature $\left({ }^{\circ} \mathrm{C}\right)$} & 500 & 450 & 500 \\
\hline \multicolumn{2}{|c|}{ Flow (g/min) } & 35 & 35 & 35 \\
\hline \multicolumn{2}{|c|}{ Pressure (psia) } & 14.7 & 14.7 & 14.7 \\
\hline \multicolumn{2}{|c|}{ Total run time (min) } & 60 & 90 & 60 \\
\hline \multicolumn{2}{|c|}{ Micro carbon residue (weight \%) } & 25.7 & 23.8 & 25.1 \\
\hline \multicolumn{2}{|c|}{ Insolubles in n-C7 (weight \%) } & 22.6 & 23 & 25.3 \\
\hline \multicolumn{2}{|c|}{ P-value } & - & 1.5 & 1.3 \\
\hline \multicolumn{2}{|c|}{ Merit test } & 7.0 & - & - \\
\hline \multicolumn{2}{|c|}{ Type of stability } & Stable & Stable & Stable \\
\hline \multicolumn{2}{|c|}{ Viscosity at $80^{\circ} \mathrm{C}(\mathrm{cP})$} & 8735 & 6480 & 10970 \\
\hline \multicolumn{2}{|c|}{ Viscosity at $100^{\circ} \mathrm{C}(\mathrm{cP})$} & 1524 & 1234 & 2075 \\
\hline \multicolumn{2}{|c|}{ Viscosity at $120^{\circ} \mathrm{C}(\mathrm{cP})$} & 419 & 357 & 558 \\
\hline \multicolumn{2}{|c|}{ Total metals $(\mathrm{mg} / \mathrm{kg})$} & 723.4 & 712.7 & 836.4 \\
\hline \multirow{5}{*}{ Net Balance } & $\%$ Gas & 0.01 & 4.72 & 0.09 \\
\hline & \% Naphtha & 4.82 & 3.96 & 16.63 \\
\hline & $\%$ Heavier distillates & 97.54 & 89.48 & 82.61 \\
\hline & $\%$ Coke & 0.04 & 0.16 & 0.50 \\
\hline & $\%$ Total & 102.4 & 98.3 & 99.8 \\
\hline
\end{tabular}




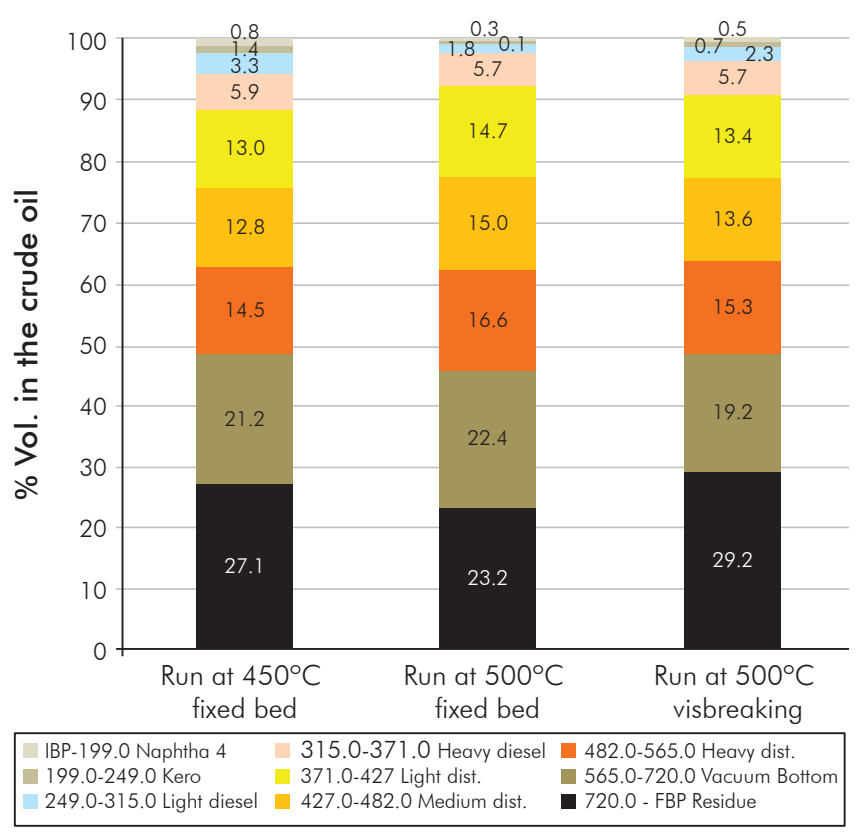

Figure 3. Fractions obtained in normal visbreaking and the thermal fixed-bed process - Reduced Oil A.

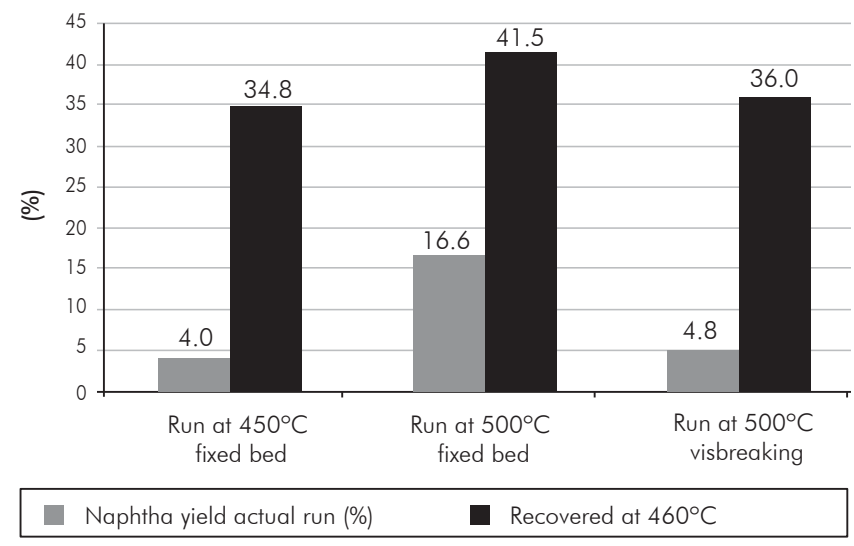

Figure 4. Percentage recovered at $460^{\circ} \mathrm{C}$ and naphtha yields by type of process - Reduced Oil A.

\section{Curves of the Product Recovery Percentage}

Figure 5 shows the product recovery percentage curves for the normal visbreaking and thermal fixed-bed processes using Reduced Oil A.

\section{Reduced Oil B}

\section{Overall Results}

Table 5 shows the operating conditions with results of the mass balances and physical chemical properties in the normal visbreaking and thermal fixed-bed processes for Reduced Oil B.

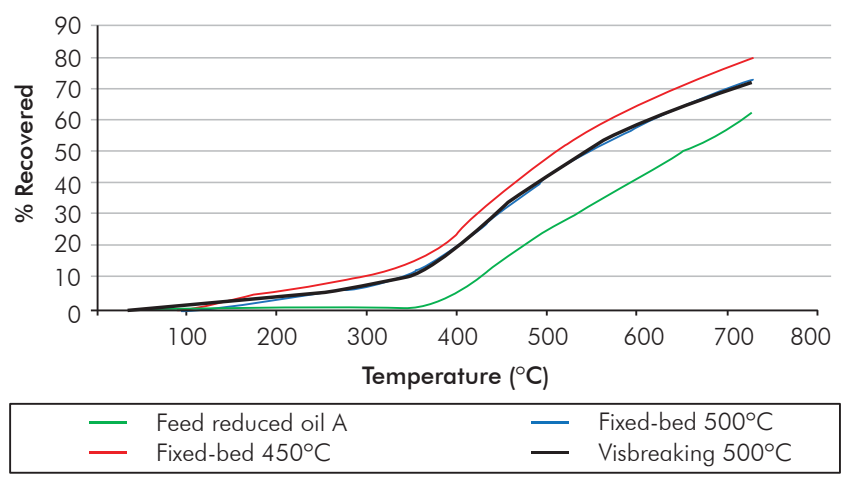

Figure 5. Composite product curves by type of process - Reduced Oil A.

\section{Yield by Distilled Fractions}

Figure 6 shows the different fractions obtained in the normal visbreaking and thermal fixed-bed processes using Reduced Oil B.

\section{Percentage Recovered at $460^{\circ} \mathrm{C}$ and Naphtha Yields}

Figure 7 shows the results of the percentages recovered at $460^{\circ} \mathrm{C}$ and the naphtha yields of the normal visbreaking and the thermal fixed-bed processes using Reduced Oil B. 
Table 5. Overall results for Reduced Oil B.

\begin{tabular}{|c|c|c|c|c|}
\hline \multirow{2}{*}{\multicolumn{2}{|c|}{ Data analyzed }} & \multicolumn{3}{|c|}{ Type of process } \\
\hline & & Visbreaking & Fixed-bed & Fixed-bed \\
\hline \multicolumn{2}{|c|}{ Residence time in isothermal zone (min) } & 2.26 & 0.85 & 0.85 \\
\hline \multicolumn{2}{|c|}{ Reaction temperature $\left({ }^{\circ} \mathrm{C}\right)$} & 500 & 450 & 500 \\
\hline \multicolumn{2}{|c|}{ Flow (g/min) } & 35 & 35 & 35 \\
\hline \multicolumn{2}{|c|}{ Pressure (psia) } & 14.7 & 14.7 & 14.7 \\
\hline \multicolumn{2}{|c|}{ Total run time (min) } & 60 & 60 & 50 \\
\hline \multicolumn{2}{|c|}{ Micro carbon residue (weight \%) } & 17.8 & 18.4 & 18.56 \\
\hline \multicolumn{2}{|c|}{ Insolubles in n-C7 (weight \%) } & 14 & 16.62 & 16.21 \\
\hline \multicolumn{2}{|c|}{ P-value } & - & 1.05 & 1.05 \\
\hline \multicolumn{2}{|c|}{ Merit test } & 8.50 & - & - \\
\hline \multicolumn{2}{|c|}{ Type of stability } & Unstable & Unstable & Unstable \\
\hline \multicolumn{2}{|c|}{ Viscosity at $80^{\circ} \mathrm{C}(\mathrm{cP})$} & 392 & 6665 & 681 \\
\hline \multicolumn{2}{|c|}{ Viscosity at $100^{\circ} \mathrm{C}(\mathrm{cP})$} & 141 & 514 & 217 \\
\hline \multicolumn{2}{|c|}{ Viscosity at $120^{\circ} \mathrm{C}(\mathrm{cP})$} & 67.37 & 165 & 90 \\
\hline \multicolumn{2}{|c|}{ Total metals $(\mathrm{mg} / \mathrm{kg})$} & 200.2 & 246.2 & 226.3 \\
\hline \multirow{5}{*}{ Net Balance } & $\%$ Gas & 0.03 & 14.50 & 0.07 \\
\hline & $\%$ Naphtha & 5.81 & 2.43 & 14.61 \\
\hline & $\%$ Heavier distillates & 91.29 & 83.86 & 94.42 \\
\hline & $\%$ Coke & 0.94 & 0.43 & 0.55 \\
\hline & $\%$ Total & 98 & 101.2 & 109.6 \\
\hline
\end{tabular}

\section{Curves of the Product Recovery Percentage}

Figure 8 shows the product recovery percentage curves for the normal visbreaking and thermal fixed-bed processes using Reduced Oil B.

\section{Reduced Oil C}

Overall Results

Table 6 shows the operating conditions with results of the mass balances and physical chemical properties in the normal visbreaking and thermal fixed-bed processes for Reduced Oil C.

\section{Yield by Distilled Fractions}

Figure 9 shows the different fractions obtained in the normal visbreaking and thermal fixed-bed processes using Reduced Oil C.

\section{Percentage Recovered at $460^{\circ} \mathrm{C}$ and Naphtha Yields}

Figure 10 shows the results of the percentages recovered at $460^{\circ} \mathrm{C}$ and the naphtha yields of the normal visbreaking and the thermal fixed-bed processes using Reduced Oil C. 


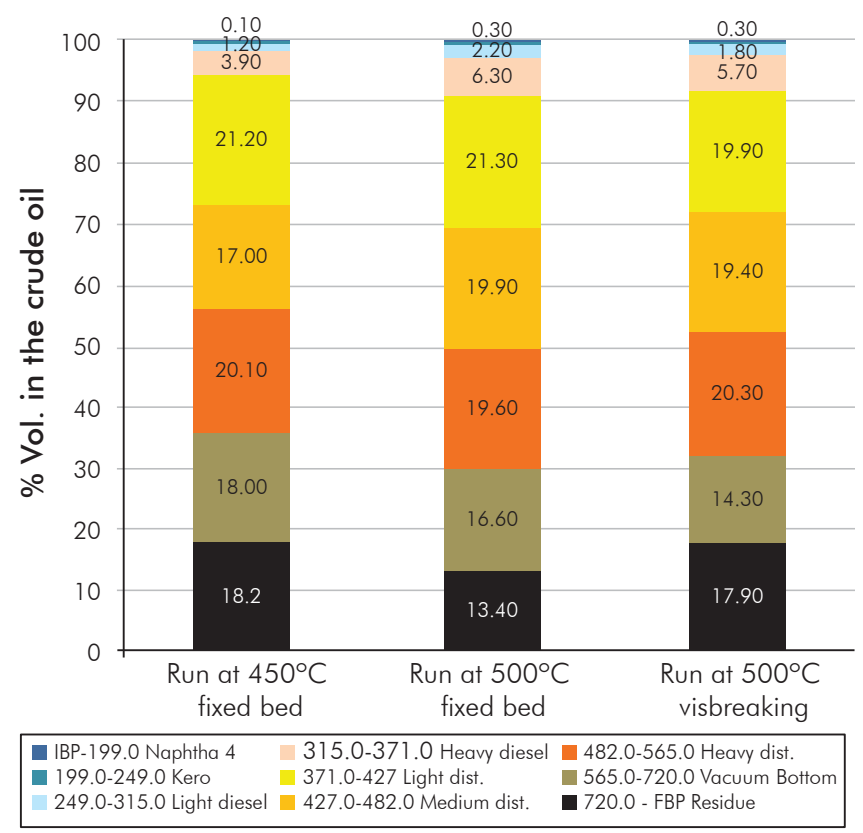

Figure 6. Fractions obtained in normal visbreaking and the thermal fixed-bed process - Reduced Oil B.

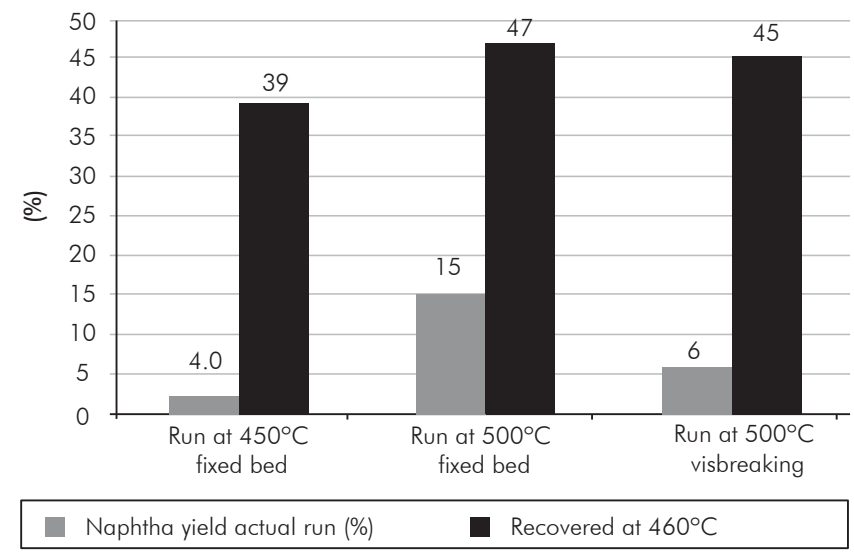

Figure 7. Percentage recovered at $460^{\circ} \mathrm{C}$ and naphtha yields by type of process - Reduced Oil B.

\section{Curves of the Product Recovery Percentage}

Figure 11 shows the composite product curves for the normal visbreaking and thermal fixed-bed processes using Reduced Oil C.

\section{Reduced Oil D}

\section{Overall Results}

Table 7 shows the operating conditions with results of the mass balances and physical chemical properties in the normal visbreaking and thermal fixed-bed processes for Reduced Oil D.

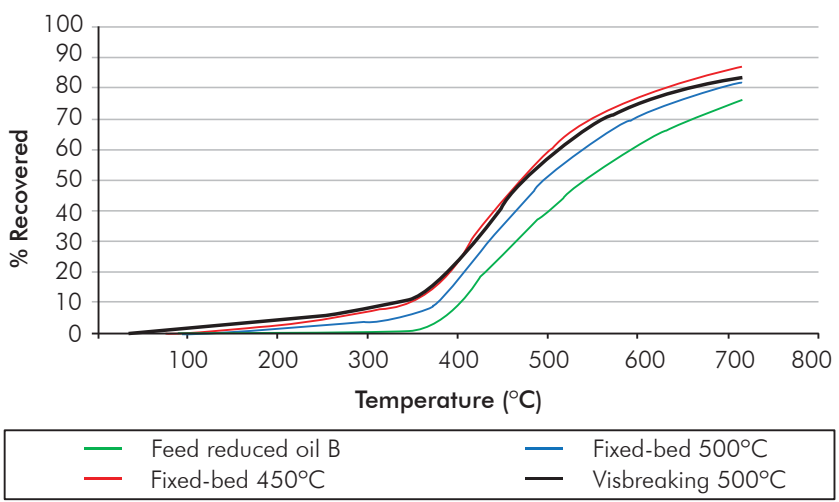

Figure 8. Composite product curves by type of process - Reduced Oil B.

\section{Yield by Distilled Fractions}

Figure 12 shows the different fractions obtained in the normal visbreaking and thermal fixed-bed processes using Reduced Oil D.

\section{Percentage Recovered at $460^{\circ} \mathrm{C}$ and Naphtha Yields}

Figure 13 shows the results of the percentages recovered at $460^{\circ} \mathrm{C}$ and the naphtha yields of the normal visbreaking and the thermal fixed-bed processes using Reduced Oil D. 
Table 6. Overall results for Reduced Oil C.

\begin{tabular}{|c|c|c|c|c|c|c|}
\hline \multirow{2}{*}{\multicolumn{2}{|c|}{ Data analyzed }} & \multicolumn{5}{|c|}{ Type of process } \\
\hline & & Visbreaking & Fixed-bed & Fixed-bed & Fixed-bed & Fixed-bed \\
\hline \multicolumn{2}{|c|}{ Residence time in isothermal zone (min) } & 2.23 & 0.84 & 0.84 & 0.84 & 0.84 \\
\hline \multicolumn{2}{|c|}{ Reaction temperature $\left({ }^{\circ} \mathrm{C}\right)$} & 508 & 450 & 450 & 500 & 500 \\
\hline \multicolumn{2}{|c|}{ Flow (g/min) } & 35 & 35 & 35 & 35 & 35 \\
\hline \multicolumn{2}{|c|}{ Pressure (psia) } & 14.7 & 50 & 50 & 14.7 & 14.7 \\
\hline \multicolumn{2}{|c|}{ Total run time (min) } & 60 & 50 & 60 & 60 & 60 \\
\hline \multicolumn{2}{|c|}{ Micro carbon residue (weight \%) } & 15.8 & 14.2 & 15.9 & 16.0 & 16.0 \\
\hline \multicolumn{2}{|c|}{ Insolubles in n-C7 (weight \%) } & 8.6 & 11.6 & 13.0 & 12.4 & 12.4 \\
\hline \multicolumn{2}{|c|}{ P-value } & - & 1.05 & 1.05 & 1.05 & 1.05 \\
\hline \multicolumn{2}{|c|}{ Merit test } & 9 & - & - & - & - \\
\hline \multicolumn{2}{|c|}{ Type of stability } & Unstable & Unstable & Unstable & Unstable & Unstable \\
\hline \multicolumn{2}{|c|}{ Viscosity at $80^{\circ} \mathrm{C}(\mathrm{cP})$} & 92 & 249 & 275 & 247 & 170 \\
\hline \multicolumn{2}{|c|}{ Viscosity at $100^{\circ} \mathrm{C}(\mathrm{cP})$} & 37.70 & 87.66 & 100.00 & 88 & 69 \\
\hline \multicolumn{2}{|c|}{ Viscosity at $120^{\circ} \mathrm{C}(\mathrm{cP})$} & 19.45 & 39.86 & 46.08 & 43.91 & 35.59 \\
\hline \multicolumn{2}{|c|}{ Total metals $(\mathrm{mg} / \mathrm{kg})$} & 179.46 & 266.71 & 280.15 & 260.68 & 225.46 \\
\hline \multirow{5}{*}{ Net Balance } & $\%$ Gas & 3.37 & 0.05 & 21.05 & 15.12 & 11.34 \\
\hline & \% Heavier distillates & 82.4 & 87.1 & 78.3 & 81.3 & 77.4 \\
\hline & $\%$ Naphtha & 6.82 & 0.93 & 3.31 & 5.96 & 10.54 \\
\hline & $\%$ Coke & 5.48 & 0.16 & 0.14 & 0.29 & 1.15 \\
\hline & $\%$ Total & 98.0 & 88.2 & 102.8 & 102.7 & 100.5 \\
\hline
\end{tabular}

\section{Composite Product Curves}

Figure 14 shows the product recovery percentage curves for the normal visbreaking and thermal fixedbed processes using Reduced Oil D.

\section{Vacuum Bottom 1}

\section{Overall Results}

Table 8 shows the operating conditions with results of the mass balances and physical chemical properties in the normal visbreaking and thermal fixed-bed processes for Vacuum Bottom 1.

\section{Yield by Distilled Fractions}

Figure 15 shows the different fractions obtained in the normal visbreaking and thermal fixed-bed processes using Vacuum Bottom 1.

\section{Percentage Recovered at $460^{\circ} \mathrm{C}$ and Naphtha Yields}

Figure 16 shows the results of the percentages recovered at $460^{\circ} \mathrm{C}$ and the naphtha yields of the normal visbreaking and the thermal fixed-bed processes using Vacuum Bottom 1. 


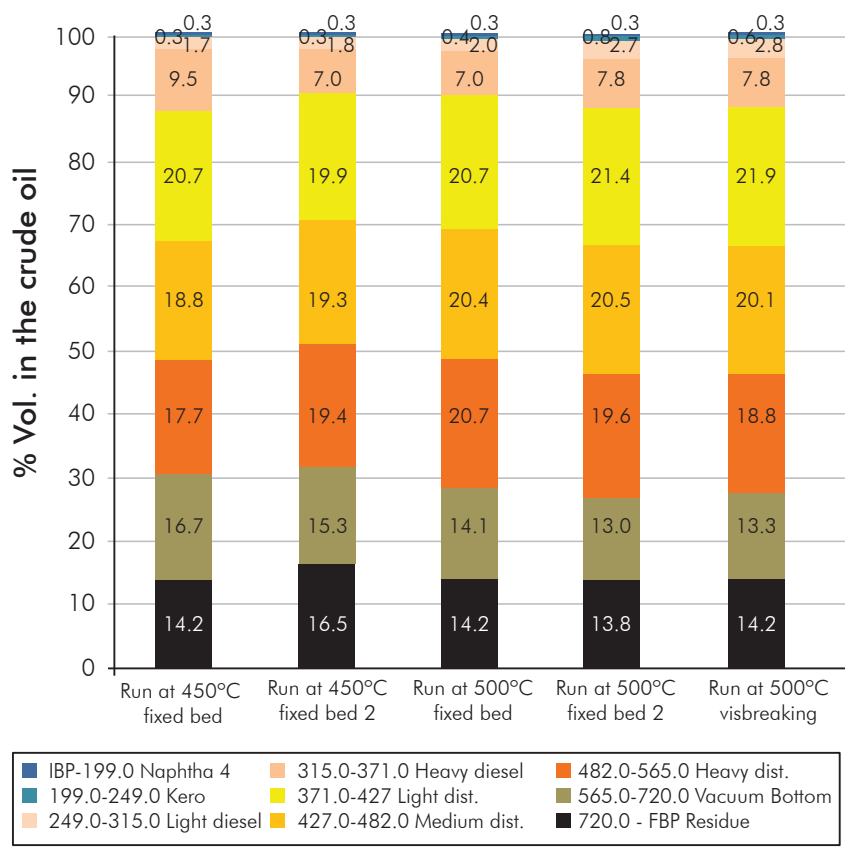

Figure 9. Fractions obtained in normal visbreaking and the thermal fixed-bed process - Reduced Oil C.

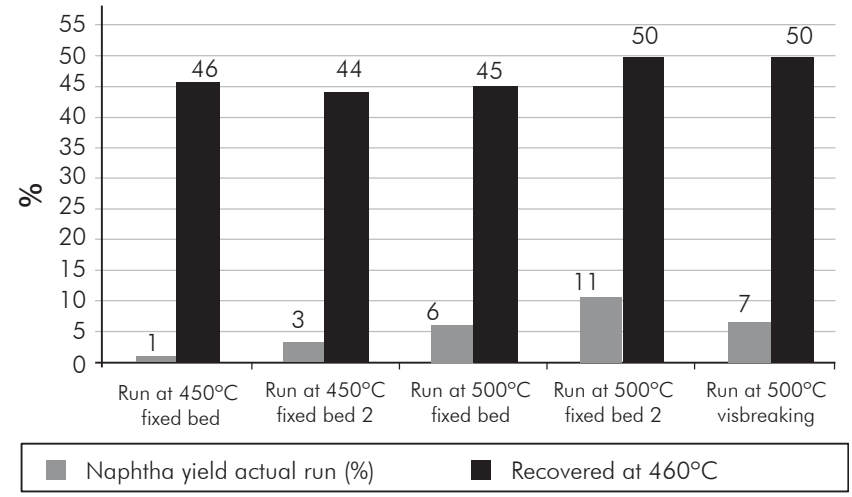

Figure 10. Percentage recovered at $460^{\circ} \mathrm{C}$ and naphtha yields by type of process - Reduced Oil C.

\section{Composite Product Curves}

Figure 17 shows the composite product curves for the normal visbreaking and thermal fixed-bed processes using Vacuum Bottom 1.

\section{Vacuum Bottom 2}

\section{Overall Results}

Table 9 shows the operating conditions with results of the mass balances and physical chemical properties in the normal visbreaking and thermal fixed-bed processes for Vacuum Bottom 2.

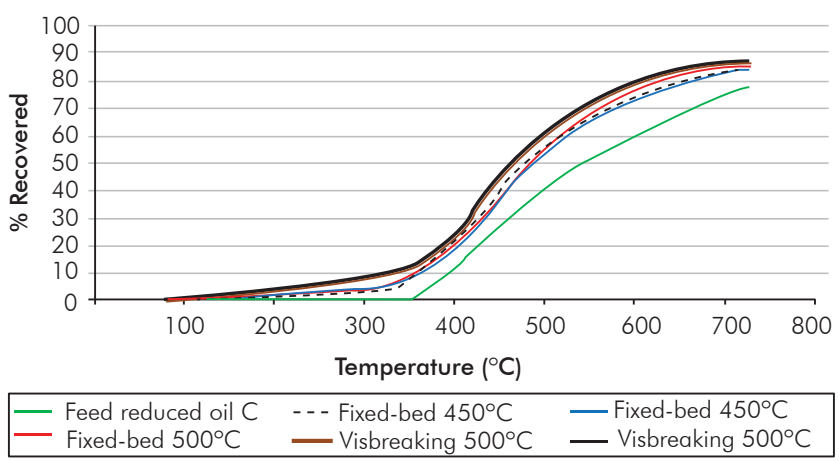

Figure 11. Composite product curves by type of process - Reduced Oil C.

Yield by Distilled Fractions

Figure 18 shows the different Fractions obtained in the normal visbreaking and thermal fixed-bed processes using Vacuum Bottom 2.

\section{Percentage Recovered at $460^{\circ} \mathrm{C}$ and Naphtha Yields}

Figure 19 shows the results of the percentages recovered at $460^{\circ} \mathrm{C}$ and the naphtha yields of the normal visbreaking and the thermal fixed-bed processes using Vacuum Bottom 2. In the experimental design, the temperature of $460^{\circ} \mathrm{C}$ was chosen to assess the yield percentage on a general level. 
Table 7. Overall results for Reduced Oil D.

\begin{tabular}{|c|c|c|c|c|c|}
\hline \multirow{2}{*}{\multicolumn{2}{|c|}{ Data analyzed }} & \multicolumn{4}{|c|}{ Type of process } \\
\hline & & Visbreaking & Fixed-bed & Fixed-bed & Fixed-bed \\
\hline \multicolumn{2}{|c|}{ Residence time in isothermal zone (min) } & 2.34 & 0.88 & 0.88 & 0.88 \\
\hline \multicolumn{2}{|c|}{ Reaction temperature $\left({ }^{\circ} \mathrm{C}\right)$} & 500 & 450 & 450 & 500 \\
\hline \multicolumn{2}{|c|}{ Flow (g/min) } & 35 & 35 & 35 & 35 \\
\hline \multicolumn{2}{|c|}{ Pressure (psia) } & 14.7 & 14.7 & 14.7 & 14.7 \\
\hline \multicolumn{2}{|c|}{ Total run time (min) } & 60 & 40 & 40 & 50 \\
\hline \multicolumn{2}{|c|}{ Micro carbon residue (weight \%) } & 25.3 & 16.3 & 16.8 & 24.9 \\
\hline \multicolumn{2}{|c|}{ Insolubles in n-C7 (weight \%) } & 23.60 & 13.88 & 15.10 & 23.50 \\
\hline \multicolumn{2}{|c|}{ P-value } & - & 1.05 & 1.10 & 1.15 \\
\hline \multicolumn{2}{|c|}{ Merit test } & 8.50 & - & - & - \\
\hline \multicolumn{2}{|c|}{ Type of stability } & Unstable & Unstable & Unstable & Unstable \\
\hline \multicolumn{2}{|c|}{ Viscosity at $80^{\circ} \mathrm{C}(\mathrm{cP})$} & 18070 & 164 & 327 & 6881 \\
\hline \multicolumn{2}{|c|}{ Viscosity at $100^{\circ} \mathrm{C}(\mathrm{cP})$} & 2301 & 63 & 103 & 1777 \\
\hline \multicolumn{2}{|c|}{ Viscosity at $120^{\circ} \mathrm{C}(\mathrm{cP})$} & 548 & 30.7 & 44.1 & 319.0 \\
\hline \multicolumn{2}{|c|}{ Total metals $(\mathrm{mg} / \mathrm{kg})$} & 642.9 & 367.8 & 366.9 & 721.0 \\
\hline \multirow{5}{*}{ Net Balance } & $\%$ Gas & 0.03 & 1.41 & 15.49 & 0.02 \\
\hline & $\%$ Naphtha & 4.74 & 2.98 & 3.10 & 7.56 \\
\hline & \% Heavier distillates & 93.9 & 88.3 & 84.7 & 86.4 \\
\hline & $\%$ Coke & 0.90 & 4.30 & 2.91 & 0.15 \\
\hline & $\%$ Total & 99.5 & 97.0 & 106.2 & 94.1 \\
\hline
\end{tabular}

\section{Curves of the Product Recovery Percentage}

Figure 20 shows the product recovery percentage curves for the normal visbreaking and thermal fixed-bed processes using Vacuum Bottom 2.

\section{DISCUSSION}

It is important to clarify that due to the physical chemical conditions of the oils, the operational unit could not be taken to the same conditions proposed in the experimental design. This has generated recommendations for improvement in future studies at the pilot plant.

\section{Yield by Distilled Fractions}

$\underline{\text { Reduced Oils }}$

In the thermal fixed-bed and normal visbreaking processes assessed in operating ranges (see Figures 3, 6, 9 and 12), it has been shown that the fixed-bed process has a higher conversion of heavy to medium fraction quantities in comparison with the normal visbreaking process (without fixed-bed).

There was large-scale production of heavy distillates for both processes, but when comparing the results between the thermal fixed-bed process and the normal 


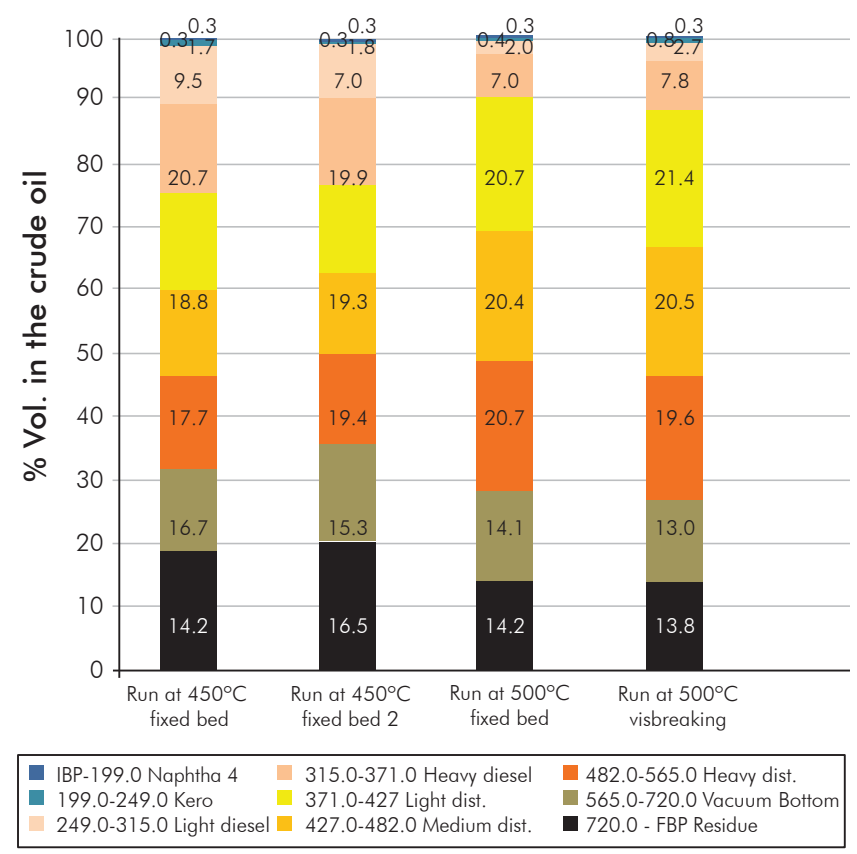

Figure 12. Fractions obtained in normal visbreaking and the thermal fixed-bed process - Reduced Oil D.

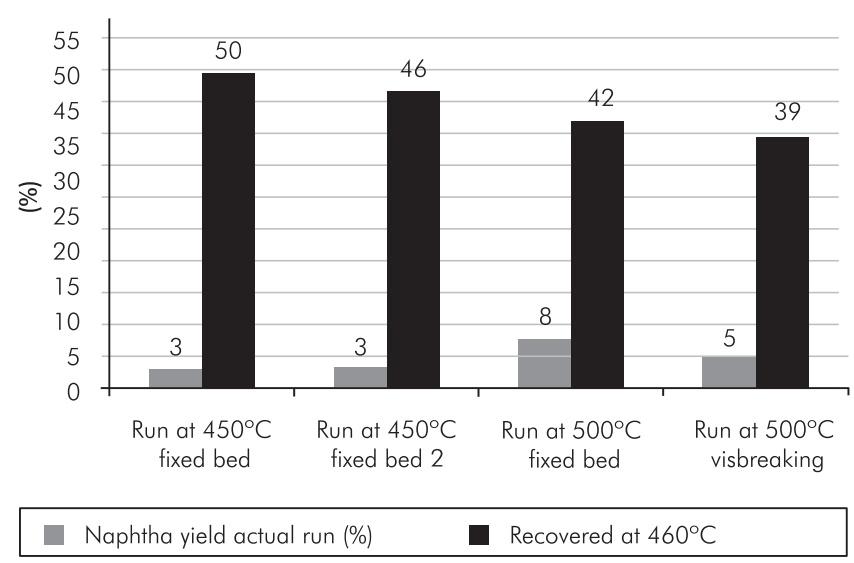

Figure 13. Percentage recovered at $460^{\circ} \mathrm{C}$ and naphtha yields by type of process - Reduced Oil D.

visbreaking process in the same conditions, the thermal fixed-bed process shows a better yield of medium fractions (see Table 10).

\section{Vacuum Bottoms}

In the case of vacuum bottoms, the tendency described is the same for reduced oils, but a little more marked (see Figures 17 and 18) because there is a higher conversion of heavy to medium fractions in the products of the process with the fixed-bed.

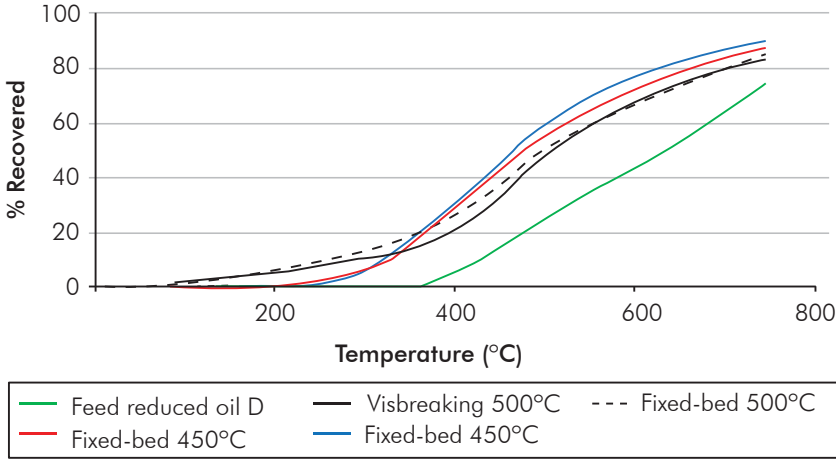

Figure 14. Composite product curves by type of process - Reduced Oil D.

This tendency to convert more heavy fractions to light fractions in the thermal fixed-bed process is thought to occur because there is a tendency for heavy fractions circulating upwards and colliding with the inert solids in the reactor to undergo additional thermal cracking on the surfaces of the inert solids fixed on the bed (Bartholic \& Watchung, 1979).

The deposition of heavy fractions on the surface of the inert solids is due to a coalescence of liquid droplets on the solid, adsorption, condensation or a combination 
Table 8. Overall results for Vacuum Bottom 1.

\begin{tabular}{|c|c|c|c|c|}
\hline \multirow{2}{*}{\multicolumn{2}{|c|}{ Data analyzed }} & \multicolumn{3}{|c|}{ Type of process } \\
\hline & & Visbreaking & Fixed-bed & Fixed-bed \\
\hline \multicolumn{2}{|c|}{ Residence time in isothermal zone (min) } & 2.32 & 0.87 & 0.87 \\
\hline \multicolumn{2}{|c|}{ Reaction temperature $\left({ }^{\circ} \mathrm{C}\right)$} & 500 & 450 & 500 \\
\hline \multicolumn{2}{|c|}{ Flow (g/min) } & 35 & 35 & 35 \\
\hline \multicolumn{2}{|c|}{ Pressure (psia) } & 15 & 15 & 15 \\
\hline \multicolumn{2}{|c|}{ Total run time (min) } & 35 & 30 & 30 \\
\hline \multicolumn{2}{|c|}{ Micro carbon residue (weight \%) } & 28.5 & 26.3 & 36.9 \\
\hline \multicolumn{2}{|c|}{ Insolubles in $\mathrm{n}-\mathrm{C7}$ (weight \%) } & 26.2 & 23.5 & 31.3 \\
\hline \multicolumn{2}{|c|}{ P-value } & - & 1.60 & 1.25 \\
\hline \multicolumn{2}{|c|}{ Merit test } & 8 & - & ND \\
\hline \multicolumn{2}{|c|}{ Type of stability } & Unstable & Stable & - \\
\hline \multicolumn{2}{|c|}{ Viscosity at $80^{\circ} \mathrm{C}(\mathrm{cP})$} & 275100 & 2350 & - \\
\hline \multicolumn{2}{|c|}{ Viscosity at $100^{\circ} \mathrm{C}(\mathrm{cP})$} & 39400 & 622 & - \\
\hline \multicolumn{2}{|c|}{ Viscosity at $120^{\circ} \mathrm{C}(\mathrm{cP})$} & 4515 & 292 & 19929 \\
\hline \multicolumn{2}{|c|}{ Total metals $(\mathrm{mg} / \mathrm{kg})$} & 524.5 & 484.9 & 598.4 \\
\hline \multirow{5}{*}{ Net Balance } & $\%$ Gas & 4.83 & 11.98 & 2.58 \\
\hline & $\%$ Naphtha & 5.79 & 13.61 & 32.03 \\
\hline & $\%$ Heavier distillates & 80.25 & 49.70 & 61.01 \\
\hline & $\%$ Coke & 9.09 & 1.78 & 4.43 \\
\hline & $\%$ Total & 100.0 & 77.1 & 100.1 \\
\hline
\end{tabular}

of these mechanisms. This takes place because the heavy fractions are in the liquid oil phase due to high boiling points and not in the vapor phase of the same oil that goes through the same bed (Bartholic \& Watchung, 1979).

In addition to the above, in previous studies in which inert solids were added to thermal processes, it was clearly shown that the activation energies for the reactions involved when carrying out thermal cracking with inert solids are lower than when thermal cracking is carried out only on oil (Phillips, Haidar \& Poon,
1985). The drop in activation energies when there are inert solids present may be due to the following mechanism:

- A catalytic step at the beginning of the reaction, in which the inert solids "act" as catalysts (Phillips et al., 1985).

- A thermal step in which the particles of inert solids lose their catalytic activity as they are wrapped in a layer of coke (Phillips et al., 1985). 


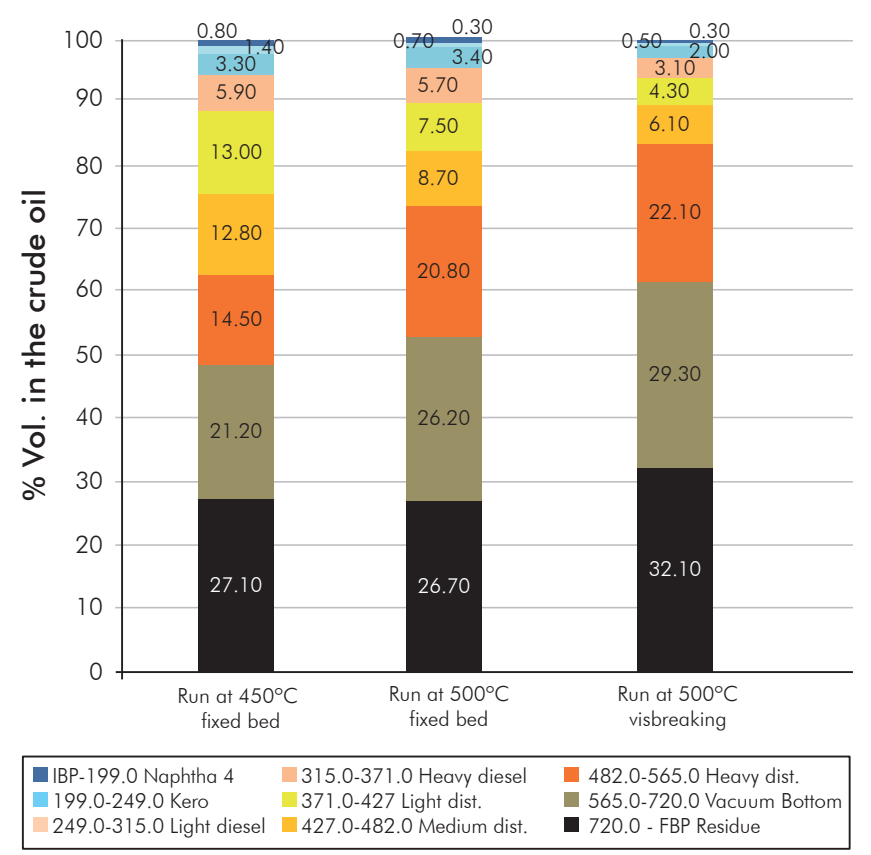

Figure 15. Fractions obtained in normal visbreaking and the thermal fixed-bed process - Vacuum Bottom 1.

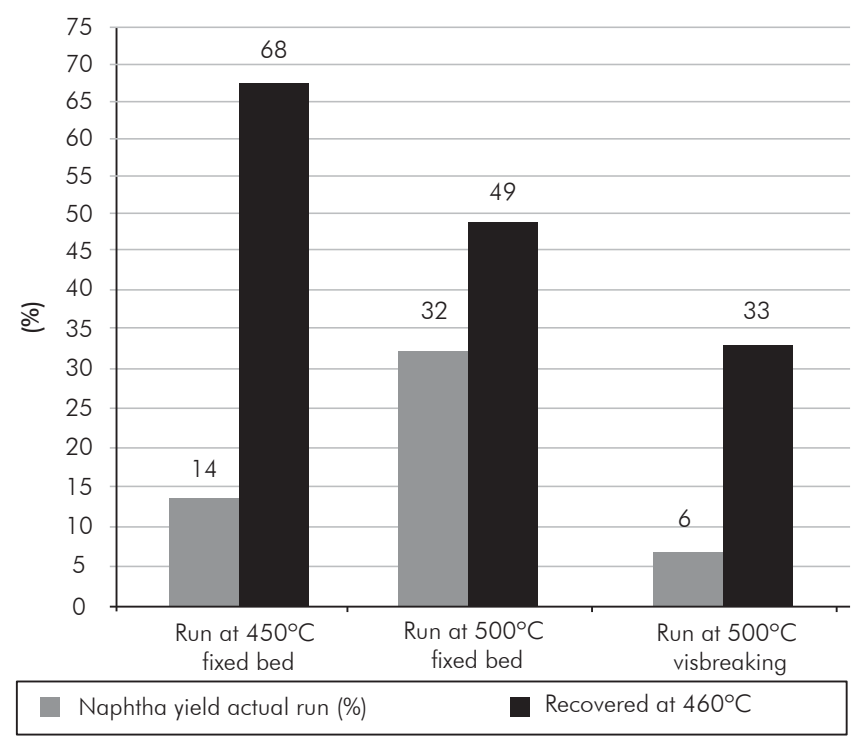

Figure 16. Percentage recovered at $460^{\circ} \mathrm{C}$ and naphtha yields by type of process - Vacuum Bottom 1.

A low activation energy is expected in the catalytic step, and the activation of the reaction is average. According to Phillips et al. (1985), while the activation energy values remain in the thermal cracking region, it can be assumed that the catalytic step is small compared to the thermal step. Alternately, the effect of the inert solids is merely physical, increasing the surface area of the reaction zone and preventing the cracked molecules from leaving the reaction zone, which increases the probability of bimolecular reactions and, therefore, additional cracking on the surfaces of the inert solids (Phillips et al., 1985). As a result, there is a further increase in the conversion of heavy fractions to light fractions.

The values of activation energy for thermal cracking without inert solids range from 170 to $300 \mathrm{~kJ} / \mathrm{mol}$, while the values with inert solids range from 24.3 to $56.9 \mathrm{~kJ} / \mathrm{mol}$. (Phillips et al., 1985).

The phenomenon described above makes the thermal fixed-bed process provide a higher conversion

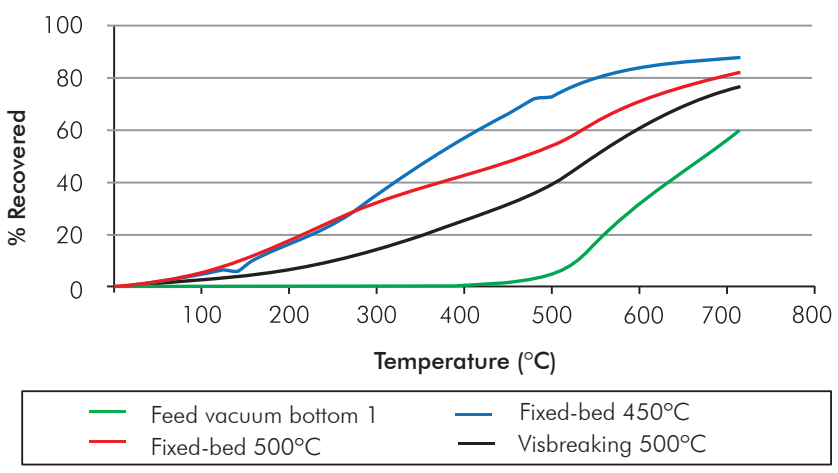

Figure 17. Composite product curves by type of process - Vacuum Bottom 1. 
Table 9. Overall results for Vacuum Bottom 2.

\begin{tabular}{|c|c|c|c|}
\hline \multirow{2}{*}{\multicolumn{2}{|c|}{ Data analyzed }} & \multicolumn{2}{|c|}{ Type of process } \\
\hline & & Visbreaking & Fixed-bed \\
\hline \multicolumn{2}{|c|}{ Residence time in isothermal zone (min) } & 2.41 & 0.91 \\
\hline \multicolumn{2}{|c|}{ Reaction temperature $\left({ }^{\circ} \mathrm{C}\right)$} & 500 & 500 \\
\hline \multicolumn{2}{|c|}{ Flow (g/min) } & 35 & 35 \\
\hline \multicolumn{2}{|c|}{ Pressure (psia) } & 14.7 & 14.7 \\
\hline \multicolumn{2}{|c|}{ Total run time (min) } & 80 & 40 \\
\hline \multicolumn{2}{|c|}{ Micro carbon residue (weight \%) } & & 42.2 \\
\hline \multicolumn{2}{|c|}{ Insolubles in $\mathrm{n}-\mathrm{C7}$ (weight \%) } & 48.3 & 41.95 \\
\hline \multicolumn{2}{|c|}{ Merit test } & 8 & \\
\hline \multicolumn{2}{|c|}{ Type of stability } & Unstable & \\
\hline \multicolumn{2}{|c|}{ Viscosity at $210^{\circ} \mathrm{C}(\mathrm{cP})$} & 565 & \\
\hline \multicolumn{2}{|c|}{ Total metals $(\mathrm{mg} / \mathrm{kg})$} & 1320 & 1228 \\
\hline \multirow{5}{*}{ Net Balance } & $\%$ Gas & 0.04 & 0.04 \\
\hline & \% Naphtha & 3.81 & 12.36 \\
\hline & $\%$ Heavier distillates & 90.78 & 76.30 \\
\hline & $\%$ Coke & 0.66 & 0.62 \\
\hline & $\%$ Total & 95.28 & 89.32 \\
\hline
\end{tabular}

than that of the normal visbreaking process at the same temperature.

Table 10 shows the additional yields obtained in the thermal fixed-bed process compared to the normal visbreaking process.

Table 10. Average percentages of conversion from heavy to medium fractions.

\begin{tabular}{|cc|}
\hline \multicolumn{2}{|c|}{ Averages } \\
\hline Average in reduced oils & $+3.40 \%$ \\
\hline Average in vacuum bottoms & $+6.00 \%$ \\
\hline Overall arithmetic average & $+4.70 \%$ \\
\hline
\end{tabular}

Residence Times, Naphtha Yield and Percentage recovered at $460^{\circ} \mathrm{C}$

Reduced Oils

Residence Times: In the fixed-bed thermal process, residence time is reduced due to the introduction of a fixed bed in the reactor. This aspect caused the thermal fixed-bed process -although the same reactor was used for both processes- to have less void volume in order for the oil to flow through the reactor. This caused the residence times in the thermal fixed-bed process to be lower than in the normal visbreaking process, although both processes handed the same mass flows (see Tables 4, 5, 6 and 7).

This provided the thermal fixed-bed process with an oil space velocity greater than that of the normal visbreaking process. 


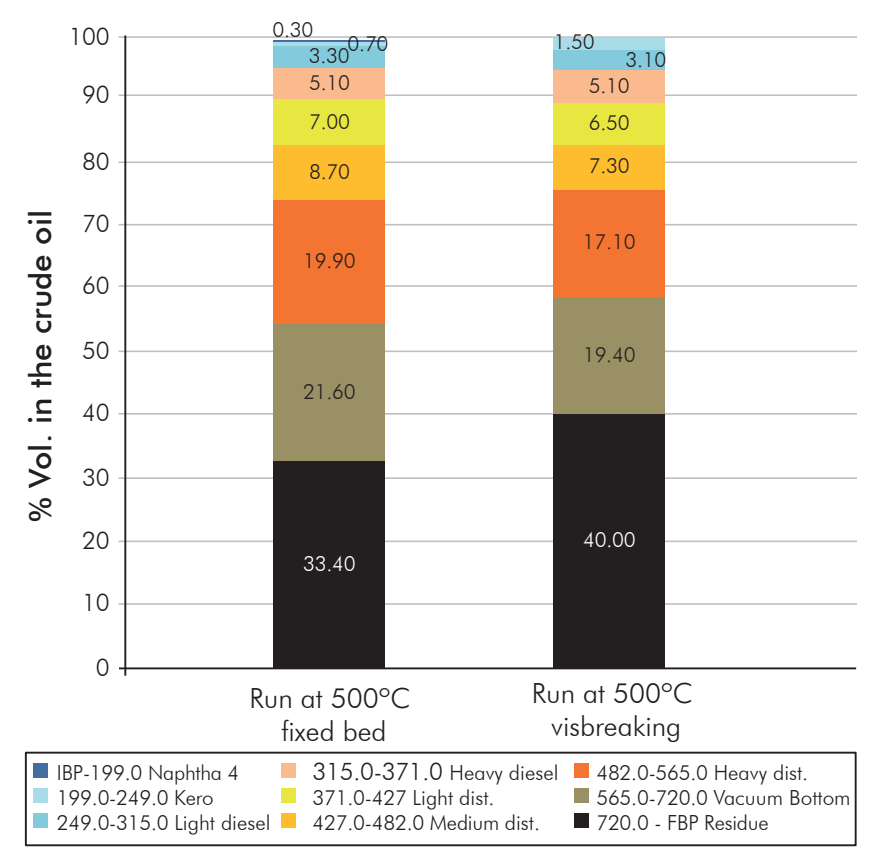

Figure 18. Fractions obtained in normal visbreaking and the thermal fixed-bed process - Vacuum Bottom 2.

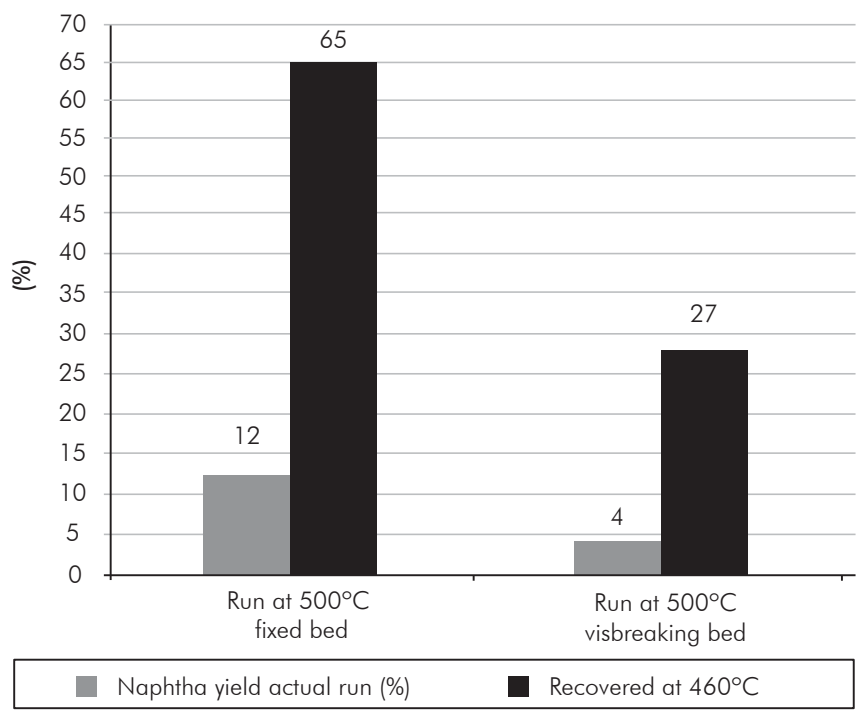

Figure 19. Percentage recovered at $460^{\circ} \mathrm{C}$ and naphtha yields by type of process - Vacuum Bottom 2.

Naphtha Yields: As you can see in Figures 4, 7, 10 and 12 , the thermal fixed-bed process has higher naphtha yields compared to the normal visbreaking process at the same process conditions. This is explained with the same principles that described the Yield by Distilled Fractions section. The higher quantities of naphthas collected during the thermal fixed-bed process are supported by the additional thermal cracking suffered by the surfaces of the inert solids in the thermal fixed-bed process, which did not occur in the normal visbreaking process.

The additional thermal cracking on the surfaces of the inert solids is also thought to occur due to the thermal micro-activity present in the inert solids, which leads to greater naphtha production in the thermal fixed-bed process.

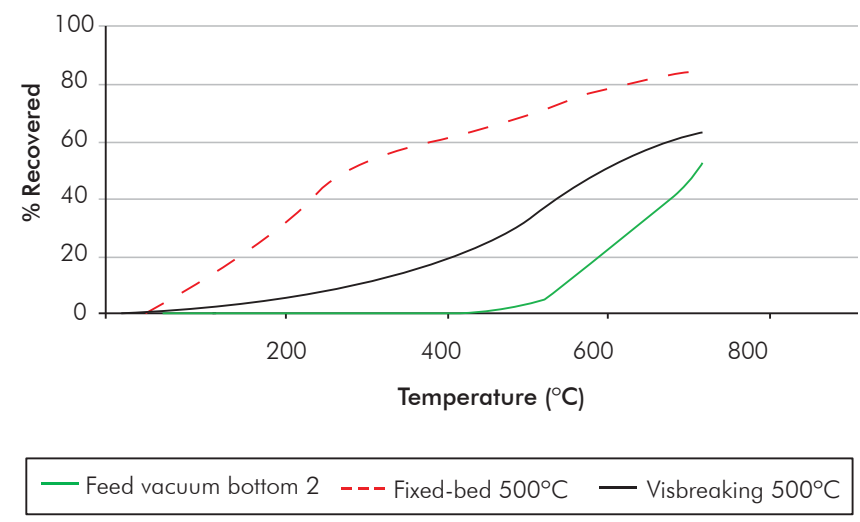

Figure 20. Composite product curves by type of process - Vacuum Bottom 2. 
Percentage Recovered for Gas Oils $\left(+460^{\circ} \mathrm{C}\right)$ : The thermal fixed-bed process shows a tendency to produce more yields in fractions of $+460^{\circ} \mathrm{C}$ than the normal visbreaking process (see Figures 4, 7, 10 and 12). This is explained with the same principles discussed in the Yield by Distilled Fractions and Residence Times, Naphtha Yield and Percentage Recovered at $460^{\circ} \mathrm{C}$ sections.

Based on these principles, the presence of inert solids in the thermal fixed-bed process leads to higher yields than the normal visbreaking process for fractions of $+460^{\circ} \mathrm{C}$.

These volumetric quantities of additional light fractions detected at $460^{\circ} \mathrm{C}$ in the thermal fixed-bed process are not detected in the normal visbreaking process because they remained in the heavy uncracked fractions.

The fractions that were not cracked in the normal visbreaking process appear as heavy fractions and, therefore, contributed to the greater yield of heavy fractions, which are distilled at higher temperatures $\left(>460^{\circ} \mathrm{C}\right)$.

\section{Vacuum Bottoms}

In the case of vacuum bottoms, the tendency described is the same for reduced oils, but a little more marked (see Tables 8 and 9 and Figures 16 and 19) because there is a higher conversion of heavy to medium fractions in the products of the thermal fixed-bed process.

\section{Curves by Distilled Fractions}

\section{Reduced Oil}

Figure 5 shows that there are higher percentages of recovered products (between 4 and 5\%) in the thermal fixed-bed process at cutting temperatures greater than approximately $300^{\circ} \mathrm{C}$ for Reduced Oil A.

In the case of Reduced Oil B, it shows that there are higher percentages of recovered products (between 1 and $2 \%$ ) in the thermal fixed-bed process at cutting temperatures greater than approximately $460^{\circ} \mathrm{C}$ (See Figure 8).

In the case of Reduced Oil C, it shows that there are similar percentages of recovered products $(+/-1 \%)$ at cutting temperatures greater than approximately $300^{\circ} \mathrm{C}$ (See Figure 11).

In the case of Reduced Oil D, it shows that there are higher percentages of recovered products (between 8 and $10 \%$ ) in the thermal fixed-bed process at cutting temperatures greater than approximately $300^{\circ} \mathrm{C}$ (See Figure 14).

This indicates that there are more medium fractions detected much quicker in the thermal fixed-bed process, than in the normal visbreaking process.

Regarding the total percentage recovered, both processes have similar results because the presence of inert solids only "converts" or "turns" heavy fractions into light ones. The presence of inert solids, which turns heavy fractions into light ones, does not affect the global mass balance of the process; it only "converts" or "transforms" heavy fractions into light ones internally, within the liquid products.

\section{Vacuum Bottoms}

There was an even greater difference with vacuum bottoms due to the larger quantity of heavy fractions in them, that were turned into light ones during the thermal fixed-bed process. The boiling point curves of the thermal fixed-bed process show higher percentages of recovery at more temperatures than the normal visbreaking process, thus indicating a greater conversion of heavy fractions to light ones (approximately 20\%) (See Figures 17 and 20).

\section{Product Quality Property}

\section{Conradson Micro Carbon Residue}

It is well known that Conradson micro carbon is a measurement used to determine oil's tendency to form carbon deposits during the evaporation thereof. Therefore, the effect of higher Conradson carbon is the increase in the portion of the feed turned into "coke", which - in this case - is deposited on the inert solid or internal surfaces of the reactor.

In addition, it is well known that the coke and metals in oil tend to concentrate in the heavy fractions because most of them have a high boiling point. These fractions, containing metals, among other things, nickel and 
vanadium, are powerful catalysts for the production of coke and hydrogen.

\section{Below are the Discussions}

Reduced Oil: In all the oils analyzed in the normal visbreaking process and the thermal fixed-bed process, there was an increase in the values of Conradson micro carbon with respect to the feed (see Tables 4, 5, 6 and 7). In addition, the values of Conradson micro carbon of the visbroken products in the thermal fixed-bed process were greater than the values found in the normal visbreaking process. This suggests that it is due to the fact that the inert solids in the thermal fixed-bed process turn more heavy fractions into light fractions (greater conversion rate), "concentrating" the polyaromatic molecules even more in the remaining heavy fractions in the visbroken product of the thermal fixed-bed process, which are the precursors of Conradson Micro Carbon. This is confirmed by the higher yield of naphthas obtained in the thermal fixed-bed process mentioned in the Residence Times, Naphtha Yield and Percentage Recovered at $460^{\circ} \mathrm{C}$ and Curves by Distilled Fractions sections.

Vacuum Bottoms: The effect on vacuum bottoms is much more marked than for reduced oils. This is explained by the fact that the vacuum bottoms contain larger quantities of heavy fractions (see Tables 8 and 9).

\section{API Gravity, P-Value and Viscosity}

The following tendencies were observed in the reduced oils and vacuum bottoms that were processed:

- Both processes have a significant reduction in viscosity with respect to the feed; however, comparing the two processes analyzed in this research, there were no significant differences between them.

- Both processes have a significant increase in API gravity with respect to the feed; however, there were no significant differences between the two processes analyzed.

- As regards the property of stability by P-Value or merit test, it was observed that they are within the limits of stability established as parameters of quality, showing tendencies toward unstable products.

\section{CONCLUSIONS}

- The thermal fixed-bed process is presented as a process for the enhancement of heavy crudes without using diluent and by means of which higher yields (approximately 5\%) are obtained from more valuable products (middle distillates) compared to the normal visbreaking process. This percentage varies $(+/-3)$ depending on the type of oil.

- The presence of inert solids in the thermal fixed-bed process helps to convert more heavy fractions into medium fractions than the normal visbreaking process. Regarding the reduced oils that were evaluated, increases in light fractions of approximately 3.4\% were observed, and for vacuum bottoms, this value was approximately $6 \%$.

- The conversion of more heavy fractions to light fractions in the thermal fixed-bed process was confirmed by the larger quantities of naphthas collected and the higher percentages recovered at temperatures close to $460^{\circ} \mathrm{C}$.

\section{ACKNOWLEDGMENTS}

The authors would like to thank Ecopetrol S.A. - Instituto Colombiano del Petróleo (ICP) for the financial aid and Luis Javier Hoyos, Engineer, for the support provided, which enabled this research.

\section{REFERENCES}

ASTM D1250 - 08. Standard Guide for Use of the Petroleum Measurement Tables. Annual Book of ASTM Standards, Vol. 05.01. ASTM International, West Conshohocken, PA, 2013.

ASTM D3279 - 12. Standard Test Method for n-Heptane Insolubles. Annual Book of ASTM Standards, Vol. 04.03. ASTM International, West Conshohocken, PA, 2012.

ASTM D4294 - 10. Standard Test Method for Sulfur in Petroleum and Petroleum Products by Energy Disper- 
sive X-ray Fluorescence Spectrometry. Annual Book of ASTM Standards, Vol. 05.02. ASTM International, West Conshohocken, PA, 2010.

ASTM D445 - 14e2. Standard Test Method for Kinematic Viscosity of Transparent and Opaque Liquids (and Calculation of Dynamic Viscosity). Annual Book of ASTM Standards, Vol. 05.01. ASTM International, West Conshohocken, PA, 2014.

ASTM D4530 - 11. Standard Test Method for Determination of Carbon Residue (Micro Method). Annual Book of ASTM Standards, Vol. 05.02. ASTM International, West Conshohocken, PA, 2011.

ASTM D5002 - 13. Standard Test Method for Density and Relative Density of Crude Oils by Digital Density Analyzer. Annual Book of ASTM Standards, Vol. 05.02. ASTM International, West Conshohocken, PA, 2013.

ASTM D5184 - 12. Standard Test Methods for Determination of Aluminum and Silicon in Fuel Oils by Ashing, Fusion, Inductively Coupled Plasma Atomic Emission Spectrometry, and Atomic Absorption Spectrometry. Annual Book of ASTM Standards, Vol. 05.02. ASTM International, West Conshohocken, PA, 2012.

ASTM D7060 - 12. Standard Test Method for Determination of the Maximum Flocculation Ratio and Peptizing Power in Residual and Heavy Fuel Oils (Optical Detection Method). Annual Book of ASTM Standards, Vol. 05.04. ASTM International, West Conshohocken, PA, 2012.

ASTM E11 - 13. Standard Specification for Woven Wire Test Sieve Cloth and Test Sieves. Annual Book of ASTM Standards, Vol. 14.02. ASTM International, West Conshohocken, PA, 2013.

Bartholic, D. B. \& Watchung, N. (1979). USA Patent 4.243.514. Preparation of FCC charge from residual fractions.

Phillips, C. R., Haidar, N. I. \& Poon, Y. C. (1985). Kinetic models for the thermal cracking of Athabasca bitumen. The effect of the sand matrix. Fuel, 64(5), 678-691.

Colyar, J. J. (2010). New upgrading technologies applicable to heavy oil and bitumen. Report, Colyar Consultants, Newtown, USA.

Corredor-Rojas, L. M. \& Valero-Alvarado, M. L. (2004). Estudio y análisis del procesamiento a nivel piloto de crudos pesados por conversión térmica. Tesis de Pregrado, Escuela de Ingeniería Química, Universidad Industrial de Santander, Bucaramanga, Colombia, 166pp.

Fogler, S. H. (1979). Elements of chemical engineering reaction engineering. New Deli: Prentice-Hall of India.

Froment, G. F. \& Bischoff, K. B. (1979). Chemical reactor analysis and design. New York: John Willey \& Sons. Inc.

Gary, J. H. \& Handwerk, G. (2001). Petroleum refining: Technology and economics. Third Edition. New York: Marcel Dekker, Inc.

Iborra, M., Tejero, J. \& Cunill, F. (2013). Reactores multifásicos. Apuntes, Universitad de Barcelona, Barcelona.

Ivanhoe Energy. (2013). HTL Process. [Online]. [Last access: July 2013]. Available at: <http://www.ivanhoeenergy. com/index.php?page $=$ htl_process_overview $>$

Levenspiel, O. (1999). Chemical reaction engineering. New York: John Willey \& Sons. Inc.

Pantoja, F. P. (2005). Proceso de viscorreducción. Seminario Proceso de Viscorreducción. Ecopetrol S.A. Barrancabermeja.

Rodríguez, L. (2014). Procedimiento técnico prueba mérito CLT-FIR-I-036. Procedimiento Técnico. Ecopetrol S.A. - Instituto Colombiano del Petróleo (ICP).

Smith, J. M. (1991). Chemical engineering kinetics. New York: McGraw-Hill, Inc.

SMS 1600. Determination of State of Peptization of Asphaltenes in Heavy Oil Streams. Shell Method Series, 2001.

UOP 389-14. Trace Metals in Organics by ICP-OES. ASTM International, West Conshohocken, PA, 2014.

\section{AUTHORS}

Judith-Rocío Santa-Jaimes

Affiliation: Ecopetrol S.A. -Instituto Colombiano del Petróleo (ICP) Chemist, Universidad Industrial de Santander M. Sc. in Chemistry, Universidad Industrial de Santander e-mail: judith.santa@ecopetrol.com.co 


\section{Jairo-Javier López-Gómez}

Affiliation: TIP Ltda.

Chemical Engineer, Universidad Pontificia Bolivariana

M. Sc. in Environmental Engineering, University of Alberta

Spe. in Process Engineering for Oil Refining and Basic

Petrochemical Industry, Universidad de San Buenaventura

e-mail: jotylopez@hotmail.com 